DOI: https://doi.org/10.24127/ajpm.v10i2.3501

\title{
PENGARUH REALISTIC MATHEMATIC EDUCATION DENGAN MEDIA REALIA TERHADAP HASIL BELAJAR MATEMATIKA
}

\author{
Muncarno $^{1 *}$, Nelly Astuti ${ }^{2}$ \\ ${ }^{1 *, 2}$ Universitas Lampung, Indonesia \\ *Corresponding author \\ E-mail: $\quad$ muncarno.muncar@gmail.com ${ }^{1 *}$ \\ nellyastuti45@gmail.com $^{2}$
}

Received 24 January 2021; Received in revised form 03 July 2021; Accepted 05 July 2021

\begin{abstract}
Abstrak
Masalah dalam penelitian ini adalah rendahnya hasil belajar peserta didik pada mata pelajaran matematika. Penelitian ini bertujuan untuk menganalisis dan mengetahui pengaruh yang signifikan pada pendekatan RME dengan media realia terhadap hasil belajar matematika peserta didik. Jenis penelitian ini yaitu eksperimen dengan desain penelitian nonequivalent control group design. Populasi penelitian ini adalah peserta didik kelas V SD Negeri 3 Metro Pusat yang berjumlah 52 peserta didik. Penentuan sampel penelitian menggunakan sampel jenuh, yaitu semua anggota populasi dijadikan sebagai sampel. Teknik pengumpulan data dilakukan dengan teknik nontes dan teknik tes. Data yang diperoleh kemudain dianalisis dengan menggunakan nilai $\mathrm{N}$-Gain untuk melihat peningkatan, dan menggunakan uji regresi sederhana untuk melihat pengaruh penggunaan pendekatan RME dan media realia terhadap hasil belajar matematika peserta didik. Berdasarkan hasil analisis disimpulkan bahwa peningkatan hasil belajar di kelas eksperimen lebih tinggi daripada kelas kontrol. Hasil pengujian hipotesis menunjukan bahwa terdapat pengaruh yang signifikan pada pendekatan RME dengan media realia terhadap hasil belajar matematika peserta didik kelas V SDN 3 Metro Pusat.
\end{abstract}

Kata kunci: Matematika; media realia; RME.

\begin{abstract}
The problem in this study is the low student learning outcomes in mathematics subjects. This study aims to analyze and determine the significant influence of RME approach with realia media on students' mathematics learning outcomes. This type of research is an experiment with non equivalent control group design research design. The population of this study was the fifth grade students of SD Negeri 3 Metro Pusat totaling 52 students. Determination of research samples using saturated samples, namely all members of the population are used as samples. Data collection techniques are carried out using test and non test techniques.Data analysist of this research are N-Gain Score and Regression Analysis. Based on the result of analysis, the final result of experiment's class higher than control's class. The results of hypothesis testing showed that there was a significant influence on the RME approach with realia media on the mathematics learning outcomes of students in class V SDN 3 Metro Pusat.
\end{abstract}

Keywords: Mathematics; realia media; RME.

This is an open access article under the Creative Commons Attribution 4.0 International License

\section{PENDAHULUAN}

Pendidikan merupakan sesuatu yang sangat diperlukan oleh setiap manusia, karena melalui pendidikan ini seseorang akan belajar mengembangkan potensi dirinya. Sebagaimana dalam Undang-undang No. 20 Tahun 2003 tentang Sistem Pendidikan Nasional Bab 1 pasal 1 ayat 1 secara tegas menyatakan bahwa Pendidikan merupakan usaha sadar dan terencana untuk mewujudkan suasana belajar dan proses pembelajaran agar peserta didik secara aktif mengembangkan potensi 
dirinya untuk memiliki kekuatan spiritual keagamaan, pengendalian diri, kepribadian, kecerdasan, akhlak mulia, serta keterampilan yang diperlukan dirinya, masyarakat, bangsa, dan negara (Pemerintah Republik Indonesia, 2003).

Berdasarkan definisi pendidikan yang telah disampaikan, diketahui bahwa tujuan pendidikan adalah mengembangkan potensi diri peserta didik untuk memiliki berbagai macam kompetensi. Salah satu indikator yang selalu dijadikan sebagai tolak ukur tercapainya tujuan pendidikan adalah hasil belajar peserta didik. Hasil belajar dapat dijadikan tolak ukur dalam menentukan tingkat keberhasilan peserta didik dalam memahami suatu mata pelajaran (Hasan, Pomalato, \& Uno, 2020).

Berdasarkan hasil observasi yang telah dilakukan di SDN 3 Metro Pusat, hasil belajar matematika peserta didik kelas $\mathrm{V}$ masih rendah atau masih banyak peserta didik yang belum mencapai KKM. Hasil belajar matematika pada mid semester ganjil kelas V A dan V B SDN 3 Metro Pusat rendah, sebagian besar belum mencapai KKM, sebanyak 46 orang dengan persentase $88 \%$. Sejatinya, pada kegiatan pembelajaran di SDN 3 Metro Pusat telah menyesuaikan dengan menggunakan kurikulum 2013. Selain itu, pendidik juga telah berusaha untuk melaksanakan pembelajaran sesuai dengan kurikulum 2013. Akan tetapi, hasil belajar peserta didik masih rendah dan belum meningkat.

Hal yang mungkin menjadi dasar terjadinya permasalahan tersebut adalah penggunaan pendekatan pembelajaran yang belum tepat. Pada proses pelaksanaan pembelajaran, penggunaan pendekatan pembelajaran yang tepat dapat membantu peserta didik untuk menyelesaikan permasalahan matematika dan dapat mengembangkan potensi atau pemahaman dirinya terkait materi pelajaran (Hasan et al., 2020).

Berdasarkan penelitian yang sudah pernah dilakukan, salah satu pendekatan yang efektif untuk digunakan dalam rangka untuk meningkatkan hasil belajar peserta didik adalah pendekatan realistic mathematics education atau dikenal dengan RME. Freudenthal sebagai pencetus RME menyatakan bahwa matematika realistik merupakah sebuah fenomena yang dialami pada setiap individu dan pandangan tentang realistik muncul sebagai bentuk perkembangan pengetahuan tentang cara berpikir manusia (Freudenthal, 2002). Pendapat lain menyatakan bahwa permasalahan realistik digunakan sebagai fondasi dalam membangun konsep matematika atau disebut sebagai sumber pembelajaran (a source for learning) (Wijaya, 2012).

RME memiliki tujuan untuk merubah pembelajaran matematika menjadi lebih menyenangkan dan bermakna bagi peserta didik dengan menggunakan konteks yang relevan dengan pengalaman maupun kehidupan peserta didik (Laurens, Batlolona, Batlolona, \& Leasa, 2018). RME merupakan suatu pendekatan yang efektif untuk digunakan dalam pembelajaran matematika karena memeberikan pengaruh positif kepada peserta didik maupun guru (Lesnussa, 2018). Berdasarkan penelitian yang pernah dilakukan, dapat disimpulkan bahwa RME cocok untuk menanggulangi permasalahan di SDN V Metro Pusat.

Permasalahan lain yang muncul dan memberikan cukup pengaruh dalam pembelajaran matematika adalah penggunaan media pembelajaran. Media pembelajaran yang sesuai dengan materi 
belajar dapat membantu komunikasi guru dan peserta didik, sehingga akan memudahkan guru untuk mencapai tujuan belajar yang optimal (Sirait \& Apriyani, 2021). Penggunaan media pembelajaran memberikan pengaruh positif terhadap hasil belajar peserta didik (Tristanti, Akbar, \& Rahayu, 2021).

Salah satu media pembelajaran yang sesuai dengan karakteristik siswa SD adalah media realia. Media realia adalah sumber belajar yang berasal dari benda nyata yang dekat dengan peserta didik yang sacara tidak langsung dapat meningkatkan ketertarikan peserta didik untuk mengikuti pembelajaran (Sari, 2020). Berdasarkan penelitian yang sudah dilakukan, diperoleh kesimpulan bahwa penggunaan media realia dapat membantu pendidik dalam rangka untuk meningkatkan hasil belajar peserta didik ((Sari, 2020); (Kuswariyanti, 2021); dan (Hastin, 2016)).

Berdasarkan karakteristik RME dan media realia yang sama-sama mengacu pada kehidupan sehari-hari, serta hasil-hasil penelitian yang menunjukkan bahwa keduanya memberikan efek positif terhadap pembelajaran matematika maka dalam penelitian ini perlu dilakukan penelitian untuk memperkuat kesimpulankesimpulan dari penelitian sebelumnya. Oleh karena itu, penelitian ini ditujukan untuk melihat pengaruh penggunaan pendekatan RME dan media realia terhadap hasil belajar matematika peserta didik

\section{METODE PENELITIAN}

Jenis penelitian yang dilakukan adalah penelitian kuantitatif dengan pendekatan eksperimen. Jenis metode yang digunakan adalah eksperimen semu (quasi experiment design). Variabel-variabel penelitian, yaitu pendekatan RME dan media realia sebagai variabel bebas, dan hasil belajar peserta didik sebagai variabel terikat.

Adapun populasi dalam penelitian ini adalah seluruh peserta didik kelas $\mathrm{V}$ SDN 3 Metro Pusat yang terdiri dari dua kelas, yaitu kelas V A dan V B yang berjumlah 52 (masing-masing kelas 26 peserta didik). Teknik pengambilan sampel yang digunakan adalah nonprobability sampling dan purposive sampling. Jenis sampel yang diambil dalam penelitian ini adalah sampel jenuh.

Rancangan desain penelitian yang digunakan adalah non-equivalent control group design. Desain nonequivalen control group design menggunakan 2 kelompok, yaitu kelompok kelas eksperimen dan kelompok kelas kontrol. Kelas V A dijadikan kelas eksperimen yang akan diberikan perlakuan menggunakan pendekatan RME dengan media realia, sedangkan kelas V B dijadikan kelas kontrol yang tidak mendapat perlakuan.

Teknik pengumpulan data menggunakan teknik nontes dan teknik tes. Teknik nontes yang digunakan adalah observasi untuk mengamati keterlaksanaan pembelajaran dengan pendekatan RME dan media realia. Sedangkan teknik tes digunakan untuk mengumpulkan data berupa nilai hasil belajar peserta didik pada ranah kognitif, dan untuk mengetahui sejauh mana tingkat penguasaan peserta didik dalam pembelajaran matematika. Bentuk tes yang diberikan berupa soal pilihan jamak.

Data yang dianalisis dalam penelitian ini adalah data kuantitatif, yaitu nilai ranah kognitif pada hasil kemampuan akhir yang diperoleh dari nilai posttest. Analisis data untuk mengetahui peningkatan pengetahuan ( $N$-Gain), menggunakan rumus berikut: 
DOI: https://doi.org/10.24127/ajpm.v10i2.3501

$$
\mathrm{G}=\frac{\text { skor postest }- \text { skor pretest }}{\text { skor maksimum-skor pretest }}
$$

Teknik analisis data pada penelitian ini adalah uji normalitas, uji homogenitas dan uji hipotesis.

1) Uji normalitas

Uji Normalitas pada penelitian ini menggunakan rumus chi kuadrat sebagai berikut:

$$
\chi^{2}=\sum_{i=1}^{k} \frac{\left(f_{o}-f_{h}\right)^{2}}{f_{h}}
$$

Keterangan:

$\chi^{2}=$ Nilai Chi Kuadrat hitung

$\boldsymbol{f}_{\boldsymbol{o}}=$ Frekuensi yang diperoleh

$\boldsymbol{f}_{\boldsymbol{h}}=$ Frekuensi yang diharapkan

Kaidah keputusan:

Jika $\chi^{2}{ }_{\text {hitung }} \leq \chi^{2}$ tabel, artinya distribusi data dinyatakan normal, sedangkan jika $\chi^{2}{ }_{\text {hitung }} \geq \chi^{2}$ tabel, artinya distribusi data dinyatakan tidak normal.

2) Uji homogenitas

Uji Homogenitas pada penelitian ini menggunakan uji-F dengan rumus:

$$
\mathrm{F}=\frac{\text { Varian terbesar }}{\text { Varian terkecil }}
$$

Keputusan uji jika $F_{\text {hitung }}<F_{\text {tabel }}$ maka homogen, sedangkan jika $F_{\text {hitung }}>F_{\text {tabel }}$ maka tidak homogen.

3) Analisis hipotesis

Analisis hipotesis pada penelitian ini menggunakan regresi sederhana. Kegunaan analisis regresi yaitu untuk meramalkan nilai variabel terikat (Y) apabila variabel (X) diketahui. Regresi sederhana dapat dianalisis karena didasari oleh hubungan fungsional atau hubungan sebab akibat variabel bebas $(\mathrm{X})$ terhadap variabel terikat $(\mathrm{Y})$. Persamaan regresi : $Y=a+b X$

\section{HASIL DAN PEMBAHASAN}

Hasil penelitian data pada kelas eksperimen dan kelas kontrol menunjukkan adanya perbedaan pada hasil belajar tematik peserta didik. Hasil tersebut dapat dilihat pada Tabel 1 .

Tabel 1. Data hasil penelitian

\begin{tabular}{cccccc}
\hline \multirow{2}{*}{ No } & \multirow{2}{*}{ Data } & \multicolumn{2}{c}{ Kelas Eksperimen } & \multicolumn{2}{c}{ Kelas Kontrol } \\
\cline { 3 - 5 } & & Pretest & Posttest & Pretest & Posttest \\
\hline 1 & $\mathrm{~N}$ & 26 & 26 & 26 & 26 \\
2 & $\sum$ & 1440 & 1930 & 1555 & 1815 \\
3 & X tertinggi & 75 & 90 & 75 & 90 \\
4 & X terendah & 35 & 50 & 40 & 50 \\
5 & Mean & 55,38 & 74,23 & 59,80 & 69,80 \\
6 & Median & 57,5 & 75 & 60 & 70 \\
7 & Modus & 60 & 75 & 60 & 70 \\
8 & Standar Deviasi & 10,86 & 9,66 & 8,77 & 10,15 \\
\hline
\end{tabular}

Berdasarkan Tabel 1, dapat dilihat bahwa dari segi jumlah nilai, mean, dan media dari kelas eksperimen meningkta lebih tinggi daripada kelas kontrol. Selain itu, untuk standar deviasi pada kelas eksperimen mengalami penurunan antara nilai pretest dan posttest. Hal ini menunjukkan bahwa persebaran nilai yang diperoleh dari subjek semakin seragam atau lebih banyak peserta didik yang memperoleh nilai di sekitar kurva normal. Atau dengan kata lain, gap antara yang memperoleh nilai tinggi dan rendah semakin kecil. Hal ini juga menunjukkan bahwa peserta didik yang awalnya 
DOI: https://doi.org/10.24127/ajpm.v10i2.3501

memperoleh nilai rendah pada pretest memperoleh nilai yang meningkat cukup signifikan pada posttest.

Setelah diketahui nilai pretest dan posttest kedua kelas, selanjutnya menghitung peningkatan hasil belajar peserta didik setelah diberi perlakuan dengan menggunakan rumus $N$-Gain. Hasil klasifikasi nilai $N$-Gain antara kelas eksperimen dan kelas kontrol dapat dilihat pada Tabel 2.

Tabel 2. Klasifikasi nilai $N$-Gain kelas eksperimen dan kelas kontrol

\begin{tabular}{llcccc}
\hline \multirow{2}{*}{ No } & \multirow{2}{*}{ Klasifikasi } & \multicolumn{2}{c}{ Krekuensi } & \multicolumn{2}{c}{ Rata-rata } \\
\cline { 3 - 6 } & & $\begin{array}{c}\text { Kelas } \\
\text { Eksperimen }\end{array}$ & $\begin{array}{c}\text { Kelas } \\
\text { Kontrol }\end{array}$ & $\begin{array}{c}\text { Kelas } \\
\text { Eksperimen }\end{array}$ \\
\hline 1 & $>0,7$ (Tinggi) & 10 & 7 & & \\
2 & $0,3-0,7$ (Sedang) & 14 & 11 & 0,62 & 0,50 \\
3 & $<0,3$ (Rendah) & 2 & 8 & & \\
\hline
\end{tabular}

Berdasarkan Tabel 2, dapat dilihat perbandingan nilai rata-rata $N$ Gain untuk kelas eksperimen dan kelas kontrol. Nilai rata-rata $N$-Gain kelas eksperimen sebesar 0,62 lebih tinggi dari kelas kontrol yang hanya 0,50 . Hal ini menunjukkan bahwa peningkatan hasil belajar di kelas eksperimen lebih signifikan dari pada kelas kontrol.

Penerapan pendekatan RME dengan media realia perlu diketahui persentase keterlaksanaanya, oleh karena itu dilakukan observasi aktivitas pendidik saat proses pembelajaran berlangsung yang dibantu oleh 2 orang observer. Hasil observasi aktivitas pendidik dituangkan dalam lembar observasi keterlaksanaan pendekatan RME dengan media realia yang terdiri dari 5 kriteria dan 20 indikator. Adapun hasil data persentase rata-rata keterlaksanaan pendekatan RME dengan media realia yaitu sebesar 92,5\%. Atau dengan kata lain, penggunaan pendekatan RME dengan media realia dalam pembelajaran terlaksana dengan maksimal. Hal ini juga menunjukkan bahwa peserta didik dapat mengikuti pembelajaran dengan baik dan tidak terkendala.

\section{Hasil Analisis Data}

\section{Uji Normalitas}

Uji normalitas menggunakan rumus Chi Kuadrat dengan bantuan Microsoft Excel. Interpretasi hasil perhitungan dilakukan dengan membandingkan $\mathrm{X}^{2}$ hitung dengan $\mathrm{X}^{2}$ tabel untuk $\mathrm{a}=0,05$ dengan $\mathrm{dk}=\mathrm{k}-1$, maka dicari pada tabel Chi-Kuadrat didapat $\mathrm{X}^{2}$ tabel sebesar 12,59. Hasil perhitungan uji normalitas secara manual pada data pretest kelas eksperimen dan kontrol diperoleh $\mathrm{X}^{2}$ hitung $<\mathrm{X}^{2}$ tabel yaitu 4,21 $<12,5$, hal tersebut menunjukkan bahwa data pretest kelas eksperimen dan kelas kontrol berdistribusi normal. Hasil perhitungan uji normalitas secara manual pada data posttest kelas eksperimen dan kelas kontrol diperoleh $\mathrm{X}^{2}$ hitung $<\mathrm{X}^{2}$ tabel yaitu $3,52<12,59$ hal tersebut menunjukkan bahwa data posttest kelas eksperimen dan kelas kontrol juga berdistribusi normal. Setelah diperoleh bahwa data dari kelas eksperimen dan kelas kontrol baik pada pretest maupun posttest berdistribusi normal, maka dilanjutkan dengan uji homogenitas. 
DOI: https://doi.org/10.24127/ajpm.v10i2.3501

\section{Uji Homogenitas}

Uji homogenitas dilakukan dengan menggunakan uji $\mathrm{F}$ dengan bantuan program Microsoft Office Excel. Interpretasi dilakukan dengan membandingkan $\mathrm{F}$ hitung dengan $\mathrm{F}$ tabel untuk $\alpha=0,05$ dengan $\mathrm{dk}=26-1=25$ (dk pembilang) dan $\mathrm{dk}=26-1=25$ (dk penyebut), maka dicari pada tabel $\mathrm{F}$ didapat $F$ tabel sebesar 1,96. Sehingga didapat data pretest $1,08<1,96$ sesuai dengan kriteria uji yang menyatakan bahwa $\mathrm{F}_{\text {hitung }}<\mathrm{F}_{\text {tabel }}$ berarti data berasal dari populasi yang homogen, dan data posttest $1,10<1,96$ sesuai dengan kriteria uji yang menyatakan bahwa $\mathrm{F}$ hitung $<\mathrm{F}$ tabel berarti data juga berasal dari populasi yang homogen. Dapat disimpulkan bahwa data pretest dan posttest keduanya berdistribusi homogen.

\section{Uji Hipotesis}

Uji hipotesis menggunakan analisis regresi. Analisis regresi digunakan untuk meramalkan nilai variabel terikat $(\mathrm{Y})$ apabila variabel $(\mathrm{X})$ diketahui. Pengambilan keputusan diterima atau ditolaknya hipotesis yang diajukan dengan mengacu pada kaidah berikut. Jika $F_{\text {hitung }}>\quad F_{\text {tabel }}$, artinya terdapat hubungan yang signifikan atau Ho ditolak dan Ha diterima, sedangkan jika $F_{\text {hitung }}<F_{\text {tabel }}$, artinya tidak terdapat hubungan yang signifikan atau Ho diterima dan $\mathrm{Ha}$ ditolak. Persamaan regresi : $\mathrm{Y}=\mathrm{a}+\mathrm{bX}$ dan diperoleh hasil $F_{\text {hitung }}>F_{\text {tabel }} \quad(9,21>4,26)$. Karena $\mathrm{F}_{\text {hitung }}$ lebih besar dari $\mathrm{F}_{\text {tabel }}$, maka $\mathrm{Ha}$ diterima dan Ho ditolak. Dengan demikian terdapat pengaruh yang signifikan antara pendekataan RME dengan media realia terhadap hasil belajar matematika di SDN 3 Metro Pusat.

Berdasarkan perhitungan tersebut menunjukkan bahwa hasil belajar tematik peserta didik kelas eksperimen lebih tinggi dibandingkan kelas kontrol. Hal ini dikarenakan kelas eksperimen pada pembelajarannya menggunakan pendekatan RME dengan media realia.

Pendekatan RME adalah pendekatan pembelajaran matematika yang bertitik tolak pada realita atau konteks nyata di sekitar peserta didik untuk mengawali kegiatan pembelajaran dan akhirnya digunakan untuk menyelesaikan masalah dalam kehidupan sehari-harinya. Pendekatan RME mampu melatih siswa untuk memahami konsep berdasarkan masalah dalam kehidupan sehari-hari. Hal ini sesuai dengan hasil penelitian sebelumnya yang memperoleh kesimpulan bahwa peningkatan kemampuan pemahaman konsep peserta didik lebih baik (Hidayat, Yandhari, \& Alamsyah, 2020).

Berdasarkan hal tersebut, penelitian menggunakan pendekatan RME karena pembelajaran menjadi lebih bermakna dan ril dengan menggunakan contoh nyata dalam kehidupan sehari hari. Hal ini sangat penting, sebab materi yang dipelajari akan tertanam erat dalam memori peserta didik, sehingga tidak akan mudah dilupakan. Sejalan dengan pendapat Laurens yang menyatakan bahwa RME memiliki tujuan untuk merubah pembelajaran matematika menjadi lebih menyenangkan dan bermakna bagi peserta didik dengan menggunakan konteks yang relevan dengan pengalaman maupun kehidupan peserta didik (Laurens et al., 2018)

Peningkatan hasil belajar peserta didik terjadi dikarenakan ketika proses pembelajaran menggunakan pendekatan RME, peserta didik dilibatkan secara aktif dalam proses pembelajarannya. Hal ini sesuai dengan hasil penelitian sebelumnya yang menyatakan bahwa 
penggunaan RME dapat meningkatkan aktivitas belajar peserta didik (Susilowati, 2018). Hal ini dikarenakan langkah-langkah dalam proses pembelajaran yang digunakan, yaitu meliputi (1) memahami masalah kontekstual yaitu pendidik menyajikan masalah kontekstual dan meminta peserta didik menelaah masalah tersebut agar dapat memahaminya. Pada kegiatan ini pendidik memberikan penjelasan seperlunya bagian-bagian tertentu yang belum dipahami peserta didik, (2) menyelesaikan masalah kontekstual yaitu peserta didik secara individu meneyelesaikan masalah kontekstual yang disajikan menurut pendapat mereka sendiri. Pendidik memotivasi peserta didik menyelesaikan masalah dengan cara mereka sendiri, (3) membandingkan dan mendiskusikan jawaban yaitu pendidik memberikan kesempatan kepada peserta didik untuk bertukar pikiran dan mendiskusikan jawabannya dalam diskusi kelompok dan dilanjutkan dengan diskusi kelas, (4) menyimpulkan berdasarkan hasil diskusi kelompok dan diskusi kelas yang dilakukan, pendidik mengarhakan peserta didik untuk menarik kesimpulan tentang konsep, definisi, teorema, prinsip atau prosedur matematika yang terkait dengan masalah kontektual yang baru diselesaikan (Susilowati, 2018).

Selain diterapkannya pendekatam RME, penggunaan media dapat menunjang proses pembelajaran. Media pembelajaran adalah alat yang dapat membantu proses belajar mengajar sehingga makna pesan yagn disampaikan menjadi lebih jelas dan tujuan pendidikan atau pembelajaran dapat tercapai dengan efektif dan efisien (Susilowati, 2018). Melalui penggunaan media, pendidik dapat meningkatkan kualitas dan kuantitas materi yang disajikan dalam pembelajaran, peserta didik dapat terlihat secara aktif baik secara fisik maupun mental, serta dapat mengurangi rasa jenuh (Lasabuda, 2017).

Media pembelajaran yang digunakan dalam penilitian ini adalah media realia. Media realia adalah media yang bersifat langsung dalam bentuk objek nyata untuk memahami konsep matematika. Media realia menjadi alat bantu visual dalam pembelajaran yang berfungsi memberikan pengalaman langsung kepada peserta didik (Afifah, 2019). Penggunaan media realia pada pembelajaran diharapkan dapat membuat peserta didik mudah dalam memahami materi pelajaran dan diharapkan pula peserta didik lebih aktif dalam pembeljaran sehingga pembelajaran menjadi menyenangkan (Hastin, 2016).

Menegaskan pendapat tersebut, pendekatan RME dengan media realia terdapat pengaruh signifikan terhadap hasil belajar matematika ((Ramadhani, 2019); (Noviani, Syahputra, \& Murad, 2017); (Jariatun, 2017)). Berdasarkan uraian di atas, dapat diketahui bahwa terdapat pengaruh yang signifikan pada penerapan pendekatan RME dengan media realia terhadap hasil belajar matematika kelas V SDN 3 Metro Pusat.

\section{KESIMPULAN DAN SARAN}

Berdasarkan hasil analisis data penelitian dan pembahasan dalam penelitian ini, maka dapat disimpulkan bahwa terdapat pengaruh yang signifikan pada penerapan pendekatan RME dengan media realia terhadap hasil belajar matematika peserta didik kelas V SD Negeri 3 Metro Pusat. Hal ini dikarenakan penggunaan pendekatan RME yang dipadukan dengan emdia realia dapat meningktkan aktivitas 
belajar peserta didik. Selain itu, peserta didik lebih mudah memahami masalah karena masalah yang digunakan adalah masalah dalam kehidupan sehari-hari.

Berdasarkan hasil penelitian, disarankan untuk penelitian selanjutnya dapat mengambil topik di jenjang kelas yang berbeda atau memadukan pendekatan lain dengan media realia sebagai bentuk upaya untuk meningkatkan kualitas pembelajaran matematika.

\section{DAFTAR PUSTAKA}

Afifah, R. N. (2019). Penggunaan Media Realia untuk Meningkatkan Hasil Belajar Siswa. Jurnal Pendidikan Guru Sekolah Dasar, 9, 891-899.

Freudenthal. (2002). Revisiting Mathematics Education. Newyork: Kluwer Academic.

Hasan, F. R., Pomalato, S. W. D., \& Uno, H. B. (2020). Pengaruh Pendekatan Realistic Mathematic Education ( RME ) terhadap Hasil Belajar Matematika Ditinjau dari Motivasi Belajar. Jambura Journal of Mathematics Education, 1(1), 13-20.

Hastin, M. (2016). Pengaruh Media Realia Terhadap Prestasi Belajar Matematika Siswa Kelas X SMK. Jurnal Pelangi, 8(2), 203-209.

Hidayat, E. I. F., Yandhari, I. A. V., \& Alamsyah, T. P. (2020). Efektivitas Pendekatan Realistic Mathematics Education ( RME ) Untuk Meningkatkan Kemampuan Pemahaman Konsep Matematika Siswa Kelas V. Jurnal Ilmiah Sekolah Dasar, 4(1), 106-113.

Jariatun. (2017). Pengaruh Penggunaan Media Realia Terhadap Hasil Belajar Matematika di Kelas IV Madrasah Ibitadiyah Negeri 2
Bandar Lampung. UIN Raden Intan Lampung.

Kuswariyanti, N. (2021). Pengembangan Media Realia untuk Meningkatkan Hasil Belajar Matematika. Prismatika: Jurnal Pendidikan Dan Riset Matematika, 3(2), 172-179.

Lasabuda, N. E. (2017). Pengembangan Media Youtube dalam Pembelajaran Matematika (Suatu Penelitian di SMK Kesehatan Bahti Nusantara Gorontalo). JPs: Jurnal RIset Dan Pengembangan Ilmu Pengetahuan, 2(2), 270-275. Laurens, T., Batlolona, F. A., Batlolona, J. R., \& Leasa, M. (2018). How Does Realistic Mathematics Education ( RME ) Improve Students ' Mathematics Cognitive Achievement? Science and Technology Education, 14(2), 569-578.

https://doi.org/10.12973/ejmste/76 959

Lesnussa, Y. A. (2018). Realistic Mathematics Education ( RME ) Provides Great Benefits for Students in Indonesia. JAMFAS, 1(1), 1-6.

Noviani, J., Syahputra, E., \& Murad, A. (2017). The Effect of Realistic Mathematic Education ( RME ) in Improving Primary School Students , Spatial Ability in Subtopic Two Dimension Shape. Journal of Education and Practice, 8(34), 112-126.

Pemerintah Republik Indonesia. $U U$ Nomor 20 Tahun 2003. , Pub. L. No. 4301 (2003).

Ramadhani, D. (2019). Pengaruh Model Pembelajaran Realistic Mathematics Education (RME) Terhadap Hasil Belajar Matematika Siswa Kelas V MIN 7 Medan Denai T.A 2018/2019. UIN Sumatera Utara. 
DOI: https://doi.org/10.24127/ajpm.v10i2.3501

Sari, A. H. (2020). Peningkatan Hasil Belajar Matematika Melalui Media Realia pada Siswa Kelas 2 SD. Jurnal PG-PAUD Trunojoyo, 7(11), 52-58.

Sirait, E. D., \& Apriyani, D. D. (2021). Pegaruh Media Pembelajaran Google Classroom dan Minat Belajar Terhadap Hasil Belajar Matematika. Prosiding Semnas Ristek, 827-831.

Susilowati, E. (2018). Peningkatan Aktivitas dan Hasil Belajar Matematika Siswa SD Melalui Model Realistic Mathematics Education (RME) pada Siswa Kelas IV Semester I di SD Negeri 4 Kradenan Kecamatan Kradenan Kabupaten Grobogan Tahun Pelajaran 2017/2018. Jurnal PINUS, 4(1), 46-53.

Tristanti, L. B., Akbar, S., \& Rahayu, A. (2021). Pengaruh Media Pembelajaran Game Edukasi Berbasis Construct terhadap Kemampuan Pemecahan Masalah dan Hasil Belajar Siswa. Mosharafa: Jurnal Pendidikan Matematika, 10(1), 129-140.

Wijaya, A. (2012). Pendekatan Matematika Realistik Suatu Alternatif Pendekatan Pembelajaran Matematika. Yogyakarta: Graha Ilmu. 